\title{
INFLUENCE OF TRUST AND CUSTOMER SATISFACTION ON REPURCHASE INTENTION AT ONLINE SHOP IN THE FACEBOOK.
}

\author{
Viajeng Purnama Putri \\ Department of Management FEB UMM \\ Email: viajengputri@gmail.com
}

\begin{abstract}
The purpose of study was to examine the influence of trust and customer satisfaction on repurchase intention. The sample in this study 100 respondents (Customer Online Shop). The sampling method was purposive sampling method from populations of customer Online Shop in the Facebook. The analysis method was path analysis. The results of path analysis show that trust and consumer satisfaction influence positive and significant effect on repurchase intention online shop in the Facebook. The trust effect as mediation between consumer satisfaction and repurchase intention.
\end{abstract}

Keywords : Trust,Consumer Satisfaction, Repurchase intention, Online Shop

\section{PENDAHULUAN}

Bagi seorang konsumen niat beli ulang terhadap suatu produk muncul dari dari sebuah keinginan yang disebabkan oleh dampak dari suatu proses pengamatan dan pembelajaran, apabila konsumen mempunyai penilaian positif maka konsumen mempunyai niat untuk membeli produk. Ferdinand (2002) Niat beli ulang yang tinggi mencerminkan tingkat kepuasan konsumen ketika akan memutuskan untuk memiliki suatu produk.

Rasa suka terhadap produk dapat dirasaan ketika konsumen merasa puas dengan produk itu, dan merasa bahwa memenuhi atau melebihi dari yang diinginkan oleh konsumen. dengan begitu produk yng ditawarkan akan bernilai semakin tinggi dimata konsumen. Sebelum memutuskan untuk membeli, ada beberapa faktor yang menjadi pertimbangan diantaranya adalah kepercayaan (trust). Karena terbatasnya akses untuk bertemu antara penjual dan pembeli maka bertransaksi online tidak memiliki kepastian dan informasi yang akurat.

Oleh sebab itu harus ada rasa saling percaya antara penjual dan pembeli.Kepercayaan konsumen pada e-commerce merupakan salah satu faktor kunci dalam me;akukan kegiatan jual beli secara online Geffen (2002). Kemudian konsumen yang pernah melakukan pembelian online dan memilii kepercayaan terhadap Online Shop, kemungkinan konsumen itu akan melakukan pembelian kembali.

Pertumbuhan Internet didorong oleh semakin baiknya kemudahan penggunaannya, biaya akses dan telekomunikasi yang makin murah, komputer yang semakin murah dan cepat dan yang paling 
penting adalah meningkatnya jumlah informasi dan hiburan.Online Shop awalnya ini merupakan salah satu bentuk atau kegiatan yang jual beli barang atau jasa yang melalui sistem elektronik, dengan melakukan transaksi pembayaran melalui mediamedia yang telah disepakati dan pengiriman barang akan dikirimkan melalui jasa pengiriman barang.

Melalui Online Shop disini pembeli dapat melihat barang atau produk yang ditawarkan tersebut melalui web yang dibuat dan dipromosikan oleh penjual Online. Online Shopping ini memungkinkan kedua belah pihak antar penjual dan pembeli tidak bertemu dan bertatap muka secara langsung Cahya (2013).Perubahan dalam bidang teknologi ini telah merubah cara hidup konsumen, cara belanja, dan berinteraksi dengan yang lainnya. Dengan adanya internet tentu akan semakin memudahkan konsumen untuk melakukan pembelian. Melalui internet, kita banyak mengenal berbagai hal, mulai dari jejaring sosial, aplikasi, berita, video, foto hingga berbelanja melalui internet atau yang sering disebut dengan Online Shopping.

Online shopping membuat konsumen semakin mudah berbelanja tanpa menghabiskan waktu dan tenaga. Karena dengan adanya kemudahan inilah membuat online Shopping semakin diminati.

Berdasarkan uraian yang telah dikemukakan tersebut, maka peneliti tertarik untuk meneliti pengaruh kepercayaan dan kepuasan pelanggan terhadap niat pembelian ulang (Repurchase Intention) Online Shop di Facebook.
Berdasarkan uraian yang diatas, maka rumusan masalah yang diambil adalah (1) Bagaimana kepercayaan konsumen terhadap Online Shop di Facebook ? (2) Bagaimana kepuasan terhadapOnline Shop di Facebook ? (3) bagaimana niat pembelian ulang Online Shop di Facebook ? (4) Apakah epercayaan berpengaruh terhadap niat pembelian ulang (Repurchase Intention) pada Online Shop di Facebook ? (5) Apakah kepuasan pelanggan berpengaruh terhadap niat pembelian ulang (Repurchase Intention)Online Shop di Facebook ? (6) Apakah kepercayaan memediasi hubungan kepuasan pelanggan pada niat pembelian ulang (Repurchase Intention) Online Shop di Facebook ?

\section{TINJAUAN PUSTAKA}

Pembelian ulang (repurchase) mempunyai definisi menurut Peter \& Olson (2002), yaitu kegiatan pembelian yang dilakukan lebih dari satu kali atau beberapa kali. Dari definisi tersebut dapat dikatakan bahwa adanya niat dari pelanggan untuk kembali membeli produk atau jasa yang sama. Hal tersebut diperoleh dari pelanggan yang puas akan pelayanan yang diberikan sehingga dapat mendorong untuk melakukan pembelian ulang (repurchase), menjadi loyal terhadap produk tersebut ataupun loyal terhadap toko tempat pelanggan tersebut membeli barang, serta dapat menceritakan hal - hal baik kepada orang lain Novantiano (2007 : 19-20). Menurut Ferdinand (2002:129) menyatakan bahwa indikator minat pembelian ulang diantaranya adalah: Minat 
Transaksional, yaitu kecenderungan seseorang untuk membeli produk, minat Referensial, yaitu kecenderungan seseorang untuk mereferensikan produk kepada orang lain, minat preferensial, yaitu minat yang menggambarkan perilaku seseorang yang memiliki preferensi utama pada produk tersebut, preferensi ini dapat berubah bila terjadi sesuatu dengan produk preferensinya, minat Eksploratif, minat ini menggambarkan perilaku seseorang yang selalu mencari informasi mengenai produk yang diminatinya dan mencari informasi untuk mendukung sifat-sifat positif dari produk tersebut.

Kepercayaan konsumen adalah semua pengetahuan yang dimiliki oleh konsumen dan semua kesimpulan yang dibuat oleh konsumen tentang objek, atribut, dan manfaatnya Mowen \& Minor (2002). Para manajer harus menyadari bahwa kepercayaan terhadap objek, atribut dan manfaat menunjukkan persepsi konsumen, dan karena itu umumnya kepercayaan seorang konsumen berbeda-beda. Hal utama yang dipertimbangkan seorang pembeli ketika melakukan kegiatan belanja secara online adalah apakah mereka percaya terhadap website yang menyediakan fasilitas layanan online shop dan percaya pada penjual online yang ada didalam di situs web tersebut beberapa hasil penelitian menunjukkan bahwa kepercayaan adalah faktor penting dalam membangun komitmen antara perusahaan dan pelanggan.

Indikator kepercayaan

menurut Gefen(2002) :Tingkat kepercayaan konsumen dengan penjual Online Shop, merasa aman dengan Online shop, percaya administrator tidak menyalah gunakan privasi pembeli dan transparan.

Pada penelitian sebelumnya, Trisnawati et al (2012) variabel kepercayaan berpengaruh positif secara signifikan pada niat beli ulang. Oleh karena itu, bila konsumen semakin baik trust maka akan mengakibatkan tingginya online Repurchase Intention. $\mathrm{H} 1$ : kepercayaan berpengaruh signifikan terhadap niat pembelian ulang (repurchase Intention).

Kepuasan konsumen (cutomer satisfaction) adalah konsep penting dalam konsep pemasaran dan penelitian konsumen. Sudah menjadi pendapat umum bahwa jika konsumen merasa puas dengan suatu produk atau merek, mereka cenderung akan terus membeli dan menggunakannya serta memberitahu orang lain tentang pengalaman mereka yang menyenangkan dengan produk tersebut. Jika mereka tidak dipuaskan, mereka cenderung beralih merek serta menajukan keberatan pada produsen, pengecer, dan bahkan menceritakannya kepada konsumen lainnya Peter \& Olson (1999).

Adapun indikator dari kepuasan konsumen yaitu Elitan (1999) :Tidak ada keluhan, perasaan senang pada keseluruhan produk, kesesuaian layanan dengan ekspektasi, harapan pelanggan yang terlampaui.

Pada penelitian sebelumnya, Julianto (2010), Customer Satisfaction berpengaruh secara Positif terhadap Purchase Intention. Nilai positif yang berarti menunjukkan hubungan yang searah.Hasil tersebut menunjukkan 
bahwa semakin besar kepuasan pelanggan, maka niat pembelian dari konsumen juga semakin besar. Pada penelitian, Ha et al. (2010), kepercayaan terbukti berperan sebagai mediasi secara parsial antara pengaruh kepuasan konsumen pada niat pembelian ulang.

$\mathrm{H} 2$ : kepuasan berpengaruh signifikan terhadap niat pembelian ulang (repurchase Intention).

H3: kepercayaan sebagai mediasi antara kepuasan dan niat pembelian ulang (Repurchase Intention)

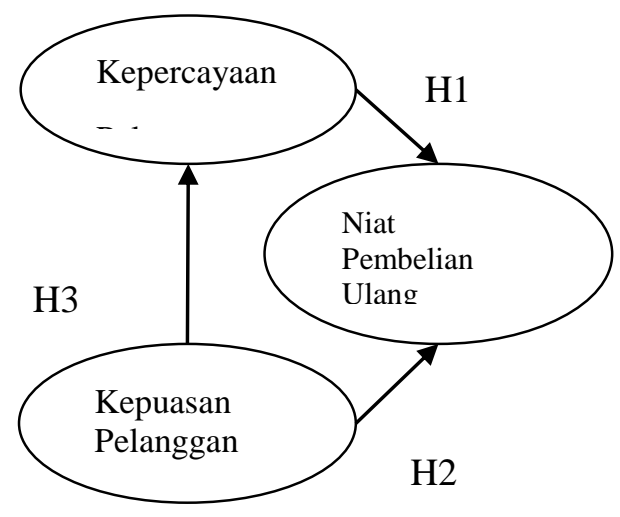

\section{Gambar 1.Kerangka Konsep}

Dalam penelitian ini variabel yang akan diteliti terdiri dari tiga variabel, yaitu kepercayaan (X1) : yaitu keyakinan pembeli Online Shop terhadap penjual Online di Facebook. Indikator dari variabel ini adalah Tingkat kepercayaan konsumen dengan penjual Online Shop, Merasa aman dengan Online shop, percaya administrator tidak menyalah gunakan privasi pembeli, merasa bahwa penjual transparan.

Kepuasan Pelanggan (X2), yaitu perasaan yang dirasakan pelanggan atas transaksi Online Shop yang dilakukan dan diterima sudah memenuhi keinginannya atau belum. Indikatornya yaitu : tidak pernah ada keluhan, perasaan senang pada keseluruhan produk, kesesuaian layanan dengan ekspektasi, harapan pelanggan yang terlampaui

Niat Pembelian Ulang (Y), yaitu suatu kemungkinan untuk memanfaatkan kembali Online Shop di Facebook di masa yang akan datang. Indikatornya yaitu : kecenderungan seseorang membeliproduk pada Online shop di Facebook, mereferensikan produk Online shop pada orang lain, preferensi utama konsumen, selalu mencari informasi mengenai produk yang diminatinya pada Online Shop di Facebook.

\section{HASIL PENELITIAN DAN PEMBAHASAN}

Hasil uji validitas dan reliabilitas menunjukkan bahwa semua instrumen data variabel kepercayaan, kepuasan pelanggan dan niat pembelian ulang yang digunakan dalah valid dan reliabel. Berikut adalah anlisis data dengan menggunakan analisis jalur, yang dijelaskan pada tabel 1 berikut:

Tabel 1. Hasil Analisis Jalur

\begin{tabular}{|c|c|c|c|c|}
\hline \multirow{2}{*}{$\begin{array}{c}\text { Model } \\
\text { B }\end{array}$} & \multicolumn{2}{|c|}{$\begin{array}{c}\text { Unstand. } \\
\text { Co. }\end{array}$} & \multirow[t]{2}{*}{$\begin{array}{c}\text { Stan } \\
\text { Co. }\end{array}$} & \multirow[t]{2}{*}{$\begin{array}{cc}\mathbf{T} & \mathbf{S i} \\
& \mathrm{g}\end{array}$} \\
\hline & $\begin{array}{l}\text { Std. } \\
\text { Error }\end{array}$ & Beta & & \\
\hline & 3.322 & 1.580 & & 2.10 .038 \\
\hline $\begin{array}{c}\text { (Constan } \\
\text { t) }\end{array}$ & & & & 2 \\
\hline $\begin{array}{c}\text { Keperca } \\
\text { yaan } \\
\text { (X1) }\end{array}$ & .278 & .101 & .270 & $\begin{array}{c}2.74 \\
9\end{array} .007$ \\
\hline $\begin{array}{c}\text { Kepuasa } \\
\text { n } \\
\text { (X2) }\end{array}$ & .503 & .119 & .417 & ${ }^{4.23} .000$ \\
\hline
\end{tabular}


Dari tabel tersebut, dapat disusun matriks koefisien jalur sebagai berikut :

$$
\left(\begin{array}{c}
\rho_{b 1 \times 1} \\
\rho_{b 2 \times 2}
\end{array}\right)=\left(\begin{array}{l}
0.270 \\
0,417
\end{array}\right)
$$

Kerangka hubungan kausal empiris antara X1 dan X2 terhadap Y dapat dibuat melalui persamaan struktural sebagai berikut :

Persamaan I :

$$
\begin{aligned}
\mathrm{Y} & =\mathrm{b} 1 \mathrm{X} 1+\mathrm{b} 2 \mathrm{X} 2+\mathrm{e} \\
& =0,270 \mathrm{X} 1+0,417 \mathrm{X} 2+0,622 \mathrm{e}
\end{aligned}
$$$$
R^{2}=0,378
$$$$
\mathrm{e}=1-R^{2}=1-0.378=0,622=62,2 \%
$$

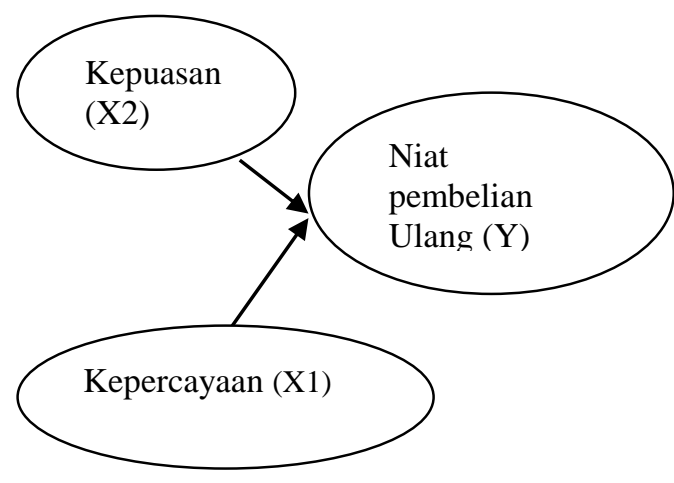

Gambar 2. Hubungan antar variabel

Berdasarkan hasil perhitungan analisis jalur struktur tersebut, maka memberikan informasi secara objektif adalah besarnya kontribusi kepercayaan (X1) yang secara langsung mempengaruhi niat pembelian ulang $(\mathrm{Y})$ adalah $0,270^{2}$ $=0,073$ atau 7,3\%. Berarti bahwa variabel kepercayaan berpengaruh secara langsung terhadap niat pembelian ulang (Repurchase Intention) tanpa melalui mediasi yaitu sebesar 7,3\%.

Besarnya kontribusi kepuasan pelanggan (X2) yang secara langsung mempengaruhi niat pembelian ulang (Y) adalah $0,417^{2}=0,174$ atau $17,4 \%$. c). Besarnya kontribusi kepercayaan (X1) dan kepuasan pelanggan (X2) berpengaruh secara simultan yang langsung mempengaruhi niat pembelian ulang (Y) adalah $0,378=37,8 \%$. Sisanya sebesar $62,2 \%$ di pengaruhi oleh faktor-faktor lain yang tidak dapat

\begin{tabular}{|c|c|c|c|c|}
\hline \multirow{2}{*}{$\begin{array}{c}\text { Mode } \\
1\end{array}$} & Uns & $\begin{array}{l}\text { and. } \\
\text { b. }\end{array}$ & \multirow{2}{*}{$\begin{array}{l}\text { Stand. } \\
\text { Co. } \\
\text { Beta }\end{array}$} & \multirow[b]{2}{*}{ T Sig. } \\
\hline & B & $\begin{array}{c}\text { Std. } \\
\text { Erro } \\
r\end{array}$ & & \\
\hline $\begin{array}{l}\text { (Const } \\
\text { ant) }\end{array}$ & 4.954 & 1.497 & & 3.310 .001 \\
\hline X2 & .682 & .097 & .581 & 7.062 .000 \\
\hline
\end{tabular}
dijelaskan dalam penelitian.

Tabel 2. Mediasi

Dari tabel tersebut dijelaskan tentang mediasi. Kerangka hubungan kausal empiris antara X2 terhadap X1 dapat dibuat melalui persamaan struktural sebagai berikut :

Persamaan II :

$$
\begin{aligned}
\mathrm{X} 1 & =\mathrm{b} 3 \mathrm{X} 2+\mathrm{e} \\
& =0,581 \mathrm{X} 2+0,663 \mathrm{e} \\
R^{2} & =0,337 \\
\mathrm{e} & =1-R^{2} \quad=1-0.337 \\
& =0,663 \quad=66,3 \% \\
\mathrm{E} & =0,663 \quad \\
\rho_{b 3 x 2} & =0,581
\end{aligned}
$$

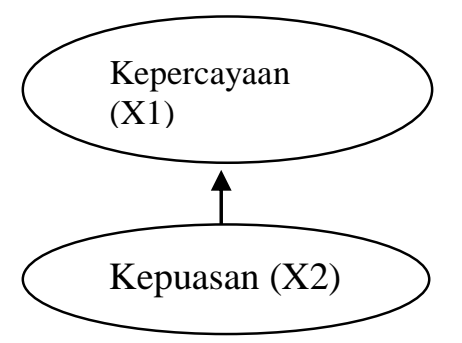

Gambar 3. Hubungan Antar Kepuasan dan kepercayaan 
Berdasarkan hasil perhitungan analisis jalur struktur tersebut, maka memberikan informasi secara objektif sebagai berikut : besarnya kontribusi kepuasan pelanggan (X2) apabila melalui mediasi kepercayaan (X1) maka, mempengaruhi sebesar $0,581^{2}=0,338$ atau $33,8 \%$.

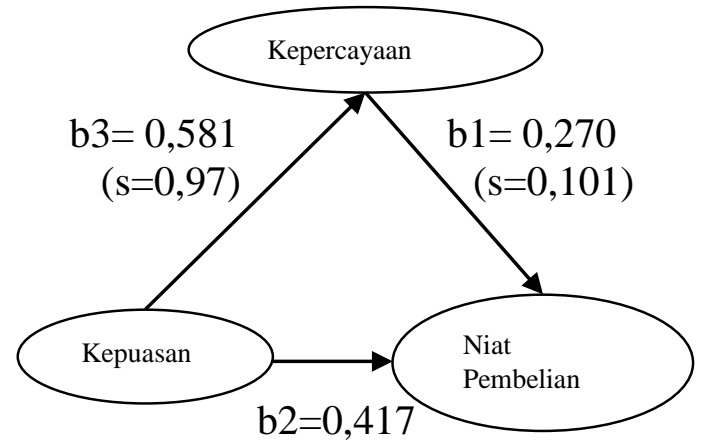

Gambar 4. Sobel Test

$b=$ Besarnya kontribusi antar variabel $\mathrm{s}=$ Std. Eror

Dari hasil pengujian sobel test diketahui bahwa kepercayaan memiliki kontribusi sebagaimediator dari kepuasan dan niat pembelian ulang.

$$
\begin{aligned}
\mathrm{Y} & =\mathrm{b} 3 \mathrm{X} 2+\mathrm{b} 1 \mathrm{X} 1 \\
& =0,581+0,270=0,851
\end{aligned}
$$

Hasil tersebut menunjukkan bahwa pengaruh kepuasan terhadap niat pembelian ulang akan lebih besar apabila melalui mediator kepercayaan, dibandingkan dengan pengaruh langsung kepuasan terhadap niatpembelian ulang tanpa melalui mediator kepercayaan. Hal ini menunjukkan bahwa, kontribusi kepercayaan sebagai mediator positif. Nilai pengaruh kepuasan apabila melalui kepercayaan lebih besardibandingkan dengan pengaruh langsung dari kepuasan pelanggan terhadap niat pembelian ulang (Repurchase Intention).

\section{HASIL PENELITIAN DAN PEMBAHASAN}

Berdasarkan hasil dengan menggunakan analisis jalur (path) dan uji hipotesis dapat diketahui bahwa:

Hipotesis pertama (H1) yang menyatakan bahwa kepercayaan berpengaruh positif terhadap niat pembelian ulang pada Online Shop di Facebook dapat diterima. Dari hasil analisis menunjukkan bahwa kepercayaan berpengaruh positif dan signifikan terhadap niat pembelian ulang pada Online Shop di Facebook.

Hal ini berarti bahwa pelanggan merasa bahwa penjual Online Shop di Facebook dapat dipercaya, pelanggan juga merasa aman dalam melakukan transaksi dengan penjual, administrator tidak menyalah gunakan privasi pembeli dan pelanggan percaya bahwa penjual transparan dalam memberikan informasi tentang produk maupun tata cara pembelian dan pengiriman barang.

Sehingga pelanggan akan melakukan pembelian berulang, karena sudah merasa percaya dengan keseluruhan yang diberikan oleh penjual. Ketika pelanggan sudah merasa sangat percaya dengan penjual Online Shop di Facebook, maka akan terus melakukan pembelian.

Hal ini menunjukkan bahwa, kepercayaan berpengaruh signifikan terhadap niat pembelian ulang. Hasil penelitian ini mendukung penelitian sebelumnya yang dilakukan oleh Trisnawati et al (2011) variabel kepercayaan berpengaruh positif secara signifikan pada niat beli ulang. 
Oleh karena itu, bila konsumen semakin percaya pada sebuah online shop maka niatnya untuk berbelanja semakin tinggi.. Penelitian ini bisa diartikan bahwa tinggi rendahnya kepercayaan menentukan tinggi rendahnya niat pembelian ulang (Repurchase Intention).

Hasil hipotesis kedua (H2) yang menyatakan bahwa kepuasan berpengaruh terhadap niat pembelian ulang dapat diterima. Dari hasil analisis menunjukkan bahwa kepuasan berpengaruh positif signifikan terhadap niat pembelian ulang. Hal ini menunjukkan bahwa semakin bertambahnya kepuasan pelanggan, maka niat pembelian ulangnya akan semakin tinggi, dan begitu juga sebaiknya.

Hasil penelitian ini sesuai dengan penelitian yang dilakukan oleh Julianto ( 2010) dalam penelitian ini dijelaskan bahwa semakin puas pelanggan, maka niat pembelian dari konsumen juga semakin besar ,apabila kepuasan pelanggan kecil, maka niat pembelian konsumen pada Online Shop di Facebook juga semakin kecil. Hasil hipotesis ketiga (H3) yang menyatakan bahwa kepuasan berpengaruh terhadap kepercayaan dapat diterima. Dari hasil analisis menunjukkan bahwa kepuasan berpengaruh positif terhadap kepercayaan. Hasil uji statistik menunjukkan bahwa Hipotesis pertama (H1) dan kedua (H2) menyatakan kepercayaan dan kepuasan pelanggan berpengaruh positif terhadap niat pembelian ulang Online Shop di Facebook dapat diterima.

Hasil analisis penelitian ini menunjukkan bahwa kepercayaan menjadi mediasi antara kepuasan pelanggan dan niat pembelian ulang (Repurchase Intention). Hasil penelitian ini sesuai dengan penelitian yang dilakukan oleh Ha et al. (2010), kepercayaan terbukti berperan sebagai mediasi secara parsial antara pengaruh kepuasan konsumen pada niat pembelian ulang.

$\begin{array}{ccc}\text { Hasil yang } & \text { terhitung } \\ \text { menunjukkan } & \text { bahwa } & \text { pengaruh }\end{array}$ kepuasan terhadap niat pembelian ulang akan lebih besar apabila melalui mediator kepercayaan, dibandingkan dengan pengaruh langsung kepuasan terhadap niat pembelian ulang tanpa melalui mediator kepercayaan. Hal ini menunjukkan bahwa, kontribusi kepercayaan sebagai mediator positif.

Melalui penelitian ini, maka fokus permasalahan yang di ajukan oleh peneliti telah terjawab. Kepercayaan pelanggan terhadap Online Shop di Facebook sangat percaya, kepuasan pelanggan terhadap Online Shop di Facebook sangat puas dan pelanggan mempunyai niatan untuk pembelian ulang Online Shop di Facebook. Kepercayaan dan kepuasan pelanggan juga berpengaruh signifikan terhadap niat pembelian ulang. Kepercayaan juga mampu memediasi antara kepuasan pelanggan terhadap niat pembelian ulang (Repurchase intention).

\section{SIMPULAN}

Berdasarkan analisis mengenai pengaruh kepercayaan dan kepuasan pelangga terhadap niat pembelian ulang (Repurchase intention) pada Online Shop di Facebook, menghasilkan kesimpulan sebagai berikut : Kepercayaan terhadap Online Shop di Facebook 
tinggi karena responden percaya bahwa penjual Online Shop di Facebook dapat dipercaya, aman dalam bertransaksi dengan penjual, privasi pembeli dalam bertransaksi terjaga dengan baik dan selalu memberikan informasi-informasi tentang produk.

Kepuasan pelanggan Online Shop di Facebook tinggi karena responden puas, senang berbelanja melalui Online Shop di Facebook, puas dalam bertransaksi dan secar keseluruhan puas dengan penjual Online Shop di Facebook melihat dari pengalaman terakhir berbelanjanya. Niat pembelian Ulang Online Shop di Facebook (Repurchase Intention) tinggi karena responden memiliki kecenderungan berbelanja melalui Online Shop di Facebook, bersedia menyarankan kepada orang lain untuk berbelanja melalui Online Shop, menjadikan Facebook sebagai preferensi utama dalam berbelanja melalui Online Shop dan selalu mencari informasi mengenai produk yang diminati pada Online Shop di Facebook.

Hasil analisis menunjukkan bahwa kepercayaan (X1) berpengaruh positif dan signifikan terhadap niat pembelian ulang (Repurchase Intention), artinya semakin tinggi kepercayaan pelanggan maka semakin tinggi niat pembelian ulang . semakin tinggi kepercayaan maka responden semakin percaya dengan penjual, percaya aman dalam bertransaksi, privasi terjaga dengan baik dan selalu diberikan informasi tentang produk sehingga semakin tinggi niat untuk melakukan pembelian ulang.

Hasil analisis menunjukkan bahwa kepuasan pelanggan (X2) berpengaruh positif dan signifikan terhadap niat pembelian ulang (Repurchase Intention), semakin puas pelanggan maka niat pembelian ulangnya akan semakin tinggi. Semakin puas maka semakin senang berbelanja melalui Online Shop di Facebook, puas dengan bertransaksi melalui Online Shop di Facebook sehingga semakin tinggi niat untuk melakukan pembelian ulang.Hasil analisis kepercayaan (X1) berpengaruh sebagai mediasi antara kepuasan pelanggan (X2) dan variabel niat pembelian ulang (Repurchase Intention) karena apabila melalui mediasi kepercayaan, maka pengaruh kepuasan terhadap niat pembelian ulang akan semakin tinggi.

\section{DAFTAR PUSTAKA}

Cahya, Anandya. 2013. Pengaruh Kepercayaan, Kemudahan, Dan Kualitas Informasi Terhadap Keputusan Pembelian Secara Online.

Calculation for the Sobel Test. 2014. An interactive calculation tool for Mediation tests.http://quantpsy.org/sobel /sobel.htm. Di akses pada tanggal 30 November 2014.

Chao, Wen, Victor, Chenyan. 2011. An Integrated Model for Customer Online Repurchase Intention.

Elitan, Lene.1999. Membangun loyalitas melalui Consumer Satisfaction dan Customer Oriented, kompak, Bandung.

Ferdinand, Augusty. 2002. Structural Equation Modelling dalam Penelitian Manajemen. Semarang:FE UNDIP. 
Ferdinand, Augusty T., 2013, Metode Penelitian manajemen, Badan penerbit Universitas Diponegoro, Semarang.

Gefen, D. (2002). Customer loyalty in e-commerce. Journal of the Association for InformationSystems, 3(1), 2751.

Ha, H-Y.; Janda, S. dan Muthaly, S. K. (2010), “A New Understanding ofSatisfaction Model in E-Re-Purchase Situation," European Journal ofMarketing, Vol. 44, No. 7/8, pp. 997-1016.

Internet World Stats, 2014. Internet World Stats Usage and Population Statistics. http:// WWW.internetworldstats.com /stats3.htm,Copyright (C) 2001 - 2014. Diakses pada tanggal 30 Oktober 2014.

Julianto, Steven. 2010. Pengaruh Perceived Risk Dan Customer Satisfaction Terhadap Purchase Intention Dan Intention To Revisit Pada Gramedia Online Surabaya.

Knabe, Peru Ann. 2009.A person's beliefs that thebehavior leads to certainoutcomes and hisevaluation of these outcomes. A Dissertation submitted to the Faculty of the Graduate School,Marquette University, in Partial Fulfillment of the Requirements forthe Degree of Doctor of Philosophy.

Kuntjara. 2007. Analisis Faktor Faktor Yang Mempengaruhi Minat Beli Ulang Konsumen pada PT Wijaya Karya Beton Wilayah IV; Jateng, DIY,
Kalsel dan Kalteng. Tesis Program Studi Magister

ManajemenProgram Pasca Sarjana Universitas Diponegoro Semarang.

Mowen, C John dan Minor, Michael. 2002. Perilaku Konsumen, Erlangga, Jakarta.

Novantiano, dan Kosahasi, Sahat. 2007. Analisa Faktor-Faktor Yang Mempengaruhi Keputusan Pembelian Ulang Barang-Barang Elektronik Buatan RRC Di Toko Hartono Elektronika.

Peter, J. Paul dan Olson, Jerry C. 1999. Consumer Behavior and Marketing Strategy fourth Edition. McGraw-Hill Irwin.

Peter, J. Paul dan Olson, Jerry C. 2002. Consumer Behavior and Marketing Strategy Sixth Edition. McGraw-Hill Irwin.

Riduwan dan Kuncoro, Engkos Ahmad. 2008. Cara Menggunakan dan Memaknai Anaslisis Jalur (path analysis), Alfabeta, Bandung.

Sanusi, Anwar. 2011. Metodologi Penelitian Bisnis. Penerbit Salemba Empat. Jakarta.

Silalahi, Ulber. 2010. Metode Penelitian Sosial. PT.Refika aditama. Bandung

Sitaniapessy, Harry A P. 2008. Pengaruh Kualitas Pelanggan Terhadap Niat Pembelian Ulang di Matahari Departement Store Ambon, volume II, nomer 2. Dosen Politeknik Negeri Ambon.

Sugiyono.2006. Metode Penelitian Bisnis. Alfabeta. Bandung.

Sutantio, Magdalena, 2004, Studi Mengenai Pengembangan 
Minat Beli Merek Ekstensi; Studi KasusProduk Sharp di Surabaya, Jurnal Sains Pemasaran Indonesia, Vol.III Tjiptono, Fandy.2005. Pemasaran Jasa, Bayumedia, Malang.

Trisnawati, Ella; Suroso, Agus; dan Kumorohadi, Untung. Analisis Faktor-Faktor Kunci Dari Niat Pembelian Kembali
Secara Online (Study Kasus Pada Konsumen Fesh Shop) Widayat. 2004. Riset Bisnis Edisi 1. Malang: CV. Cahaya Press.

Wiyono, Gendro. 2011. Merancang Penelitian Bisnis Dengan Alat Analisis SPSS $\quad 17.0$ \&SmartPLS 2.0. STIM YKPN. Yogyakarta 